\title{
A Different Effect of an Orexin Receptor Antagonist on Metabolic Parameters Between Diabetic Patients and Non- Diabetic Patients
}

\author{
Hidekatsu Yanai $^{\mathrm{a}, \mathrm{b}}$, Sumie Moriyama ${ }^{\mathrm{a}}$
}

An orexin receptor antagonist, suvorexant, has been approved as a drug for the treatment of insomnia and widely used to date in Japan. The administration of suvorexant improved glucose metabolism in $\mathrm{db} / \mathrm{db}$ mice, without affecting body weight, food intake, and insulin sensitivity [1], proposing favorable effects of suvorexant on metabolic parameters in animal models. However, effects of suvorexant on metabolic parameters in humans had been remained unknown.

Very recently, we have reported an unfavorable effect of an orexin receptor antagonist (suvorexant) on metabolic parameters and blood pressure [2]. In our study, body weight, systolic and diastolic blood pressures, hemoglobin A1c (HbA1c) and low-density lipoprotein-cholesterol (LDL-C) significantly increased at some points after the start of suvorexant. Surprisingly, suvorexant significantly reduced high-density lipoprotein-cholesterol (HDL-C) at 3, 4, 6, 8 and 9 months after its start. Because these undesirable effects are not negligible problems and more detailed analysis was desired, we analyzed them separately for diabetic patients and non-diabetic patients.

In diabetic patients $(n=45$, age, $66.9 \pm 13.4($ mean \pm SD) years; male/female, 20/25), body weight, systolic blood pressure, HbA1c, LDL-C and triglyceride (TG) did not show any changes, however, HDL-C significantly decreased at $1(\mathrm{n}=24$; from $55.0 \pm 14.0$ to $51.5 \pm 13.6 \mathrm{mg} / \mathrm{dL}, \mathrm{P}=0.036$ by paired $t$ test) and $3(\mathrm{n}=16$; from $50.9 \pm 10.6$ to $46.1 \pm 10.2 \mathrm{mg} / \mathrm{dL}, \mathrm{P}$ $=0.011)$ and 8 months $(n=9$; from $49.0 \pm 13.0$ to $43.8 \pm 10.1$ $\mathrm{mg} / \mathrm{dL}, \mathrm{P}=0.050)$ after the start of suvorexant. Diastolic blood pressure significantly increased $(\mathrm{n}=7$; from $64.9 \pm 16.5$ to $74.1 \pm 12.4 \mathrm{~mm} \mathrm{Hg}, \mathrm{P}=0.020$ ) after 8 months.

In non-diabetic patients $(n=43$, age, $48.8 \pm 20.4$ years; male/female, 14/29), body weight, systolic and diastolic blood pressures and TG did not change, however, HbAlc significantly increased at $6(\mathrm{n}=6$; from $5.8 \pm 0.5 \%$ to $6.1 \pm 0.5 \%, \mathrm{P}=$

Manuscript submitted June 10, 2018, accepted August 14, 2018

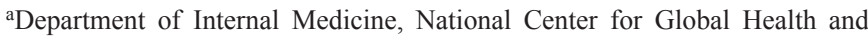
Medicine Kohnodai Hospital, Chiba, Japan

${ }^{\mathrm{b}}$ Corresponding Author: Hidekatsu Yanai, Department of Internal Medicine, National Center for Global Health and Medicine Kohnodai Hospital, 1-7-1 Kohnodai, Ichikawa, Chiba 272-8516, Japan.

Email: dyanai@hospk.ncgm.go.jp

doi: https://doi.org/10.14740/jocmr3537w
$0.022)$ and 9 months $(\mathrm{n}=3$; from $5.4 \pm 0.1 \%$ to $5.7 \pm 0.1 \%, \mathrm{P}=$ $0.010)$ after the start of suvorexant. Serum LDL-C levels were significantly elevated at $1(\mathrm{n}=12$; from $114.7 \pm 31.4$ to $126.3 \pm$ $35.2 \mathrm{mg} / \mathrm{dL}, \mathrm{P}=0.035)$ and 10 months $(\mathrm{n}=5$; from $96.0 \pm 27.7$ to $124.0 \pm 43.6 \mathrm{mg} / \mathrm{dL}, \mathrm{P}=0.044)$ after the start of suvorexant. Serum HDL-C significantly decreased at $3(\mathrm{n}=9$; from 72.1 \pm 28.0 to $66.2 \pm 31.0 \mathrm{mg} / \mathrm{dL}, \mathrm{P}=0.027)$ and 8 months $(\mathrm{n}=5$; from $69.4 \pm 23.3$ to $54.2 \pm 16.3 \mathrm{mg} / \mathrm{dL}, \mathrm{P}=0.033$ ) after the start of suvorexant. However, a significant increase of serum HDL-C was observed after 10 months $(n=4$; from $54.0 \pm 13.8$ to $60.0 \pm 15.0 \mathrm{mg} / \mathrm{dL}, \mathrm{P}=0.043$ ).

Present sub-analysis showed that suvorexant exacerbated blood pressure and lipid metabolism in diabetic patients and exacerbated glucose and lipid metabolism in non-diabetic patients. A prospective study to examine the effect of suvorexant on blood pressure, glucose and lipid metabolism is desired, and at the same time it is necessary to conduct a cohort study on the effect of suvorexant on cardiovascular events.

\section{Conflict of Interest}

The authors declares that they have no conflict of interest concerning this article.

\section{References}

1. Tsuneki H, Kon $\mathrm{K}$, Ito $\mathrm{H}$, Yamazaki M, Takahara S, Toyooka N, Ishii Y, et al. Timed inhibition of orexin system by suvorexant improved sleep and glucose metabolism in type 2 diabetic $\mathrm{db} / \mathrm{db}$ mice. Endocrinology. 2016;157(11):4146-4157.

2. Moriyama S, Yanai H, Takeuchi Y, Hayakawa T. Effects of an orexin receptor antagonist on blood pressure and metabolic parameters. J Clin Hypertens (Greenwich). 2018;20(5):978-980. 